\title{
Interactive comment on "Multi-coverage Optimal
} Location Model for Emergency Medical Services (EMS) facilities under various disaster scenarios:

\section{A case study of urban fluvial floods in the}

\section{Minhang District of Shanghai, China" by Yuhan Yang and Jie Yin}

\section{Anonymous Referee \#2}

Received and published: 3 November 2019

This study proposes a methodology for location of emergency medical services (ems) facilities under various disaster scenarios. In the introduction section, some background information and relevant literature are presented. The methodology is discussed afterwards. A case study is performed for emergency evacuation as a result of floods in the Minhang District of Shanghai, China. Overall, I think the study investigates an interesting subject and fits well with the scope of the journal. However, there are quite a few areas that have to be improved in the paper. Please find more

Printer-friendly version

Discussion paper

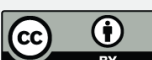


specific comments in the attached PDF document.

Please also note the supplement to this comment:

NHESSD

https://www.nat-hazards-earth-syst-sci-discuss.net/nhess-2019-214/nhess-2019-214RC2-supplement.pdf

Interactive comment on Nat. Hazards Earth Syst. Sci. Discuss., https://doi.org/10.5194/nhess2019-214, 2019.

Interactive

comment 